\title{
Aptamers as Valuable Molecular Tools in Neurosciences
}

\author{
Olga Wolter and Günter Mayer \\ Department of Chemical Biology, Life and Medical Sciences Institute, University of Bonn, 53121 Bonn, Germany
}

\begin{abstract}
Aptamers are short nucleic acids that interact with a variety of targets with high affinity and specificity. They have been shown to inhibit biological functions of cognate target proteins, and they are identifiable by an in vitro selection process, also termed SELEX (Systematic Evolution of Ligands by EXponential enrichment). Being nucleic acids, aptamers can be synthesized chemically or enzymatically. The latter renders RNA aptamers compatible with the cell's own transcription machinery and, thus, expressable inside cells. The synthesis of aptamers by chemical approaches opens up the possibility of producing aptamers on a large scale and enables a straightforward access to introduce modifications in a site-specific manner (e.g., fluorophores or photo-labile groups). These characteristics make aptamers broadly applicable (e.g., as an analytical, diagnostic, or separation tool). In this TechSight, we provide a brief overview on aptamer technology and the potential of aptamers as valuable research tools in neurosciences.
\end{abstract}

Key words: aptamer; oligonucleotide; SELEX

\section{Introduction}

The first in vitro selection experiments were reported in 1990 by three independent groups (Ellington and Szostak, 1990; Robertson and Joyce, 1990; Tuerk and Gold, 1990). Ellington and Szostak (1992) identified RNA molecules, which bind to a small organic dye and coined the term "aptamer." This term is a chimera from the Latin word "aptus," meaning "to fit" and the Greek expression "meros," meaning "part.” Tuerk and Gold (1990), in turn, introduced the acronym SELEX (Systematic Evolution of Ligands by EXponential enrichment), describing a selection process, by which they discovered a RNA molecule that binds to the bacteriophage T4 DNA polymerase. Robertson and Joyce (1990) developed in vitro selection protocols to adapt the substrate specificity of the Group I intron-ribozyme, cleaving DNA rather than RNA. These seminal reports paved the way for in vitro selection experiments to generate a plethora of synthetic functional nucleic acid molecules with novel properties and characteristics.

Aptamers are short single-chained oligo(deoxy)nucleotides (DNA or RNA) that fold into a defined 3D structure with which they bind specifically and with high affinity to defined target molecules (Fig. 1) (Ellington and Szostak, 1990). The 3D structure of aptamers depends on their primary structure, hence sequence, and on environmental conditions (e.g., buffer composition, temperature, and $\mathrm{pH}$ value) (Fig. 1A). Their binding properties are similar to those found for antibodies, being in the nanomolar to picomolar range (Meyer et al., 2011), and aptamers have been identified to distinguish between members of a protein

\footnotetext{
Received Dec. 2, 2016; revised Jan. 18, 2017; accepted Jan. 30, 2017.

This work was supported by Deutsche Forschungsgemeinschaft SFB1089 (subproject P01). We thankmembers of the Collaborative Research Center 1089 for valuable discussion and input.

We declare no competing financial interests.

Correspondence should be addressed to Dr. Günter Mayer, Department of Chemical Biology, Life and Medical Sciences Institute, University of Bonn, 53121 Bonn, Germany. E-mail: gmayer@uni-bonn.de.

DOI:10.1523/JNEUROSCI.1969-16.2017

Copyright $\odot 2017$ the authors $\quad 0270-6474 / 17 / 372517-07 \$ 15.00 / 0$
}

family, as they recognize target structures in an epitope-specific manner (Michaud et al., 2003).

Since their introduction, aptamers have been described for numerous target classes: small molecules (Ellington and Szostak, 1992), proteins, peptides (Tuerk et al., 1992), organic dyes (Holeman et al., 1998), viruses (Balogh et al., 2010), and bacteria and living cells (Tan et al., 2013), while aptamers binding to and inhibiting proteins may represent the largest cohort. Nevertheless, aptamers could potentially serve as activation tool for modulating protein conformations, enzymatic activity, and signaling networks (Hartmann et al., 1998; Win et al., 2009; Avci-Adali et al., 2013).

Consequently, an aptamer inhibiting the VEGF has been approved by the FDA for the treatment of age-related macular degeneration (Gragoudas et al., 2004; Ng et al., 2006). This breakthrough underlines the therapeutic potential of aptamers; and currently, a series of aptamers and aptamer variants are investigated in different phases of clinical trials (Hoellenriegel et al., 2014; Zhou and Rossi, 2016). Several excellent reviews were published recently, discussing the application of aptamers as diagnostics and therapeutics to which we refer here (Dassie and Giangrande, 2013; Thakur and Ragavan, 2013; Tolle and Mayer, 2013; Pei et al., 2014; Wang and Farokhzad, 2014; Pfeiffer and Mayer, 2016; Zhou and Rossi, 2016).

In addition to being considered as therapeutics, aptamers represent valuable molecular tools for the life sciences (Famulok et al., 2000). Because of their particular properties, aptamers might conquer the limitations of other commonly used inhibitors, such as antibodies and small molecules. Although antibodies are widely used as detection reagents in cell biology and standard molecular biology approaches, literally they have limited applicability as inhibitors of enzymes (Chames et al., 2009). Moreover, antibodies are associated with potential batch-to-batch variations and nonreproducible performance (Ruigrok et al., 2011; Baker, 2015). Small molecules, in turn, are broadly applied as enzyme inhibitors in cell biology studies; however, the identification of potent and specific small molecule-based inhibitors for a 
A

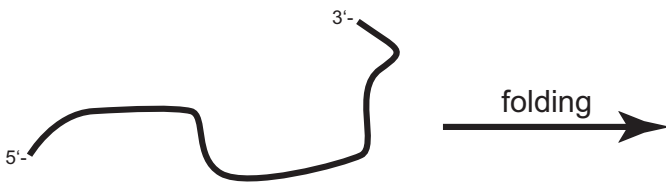

aptamer

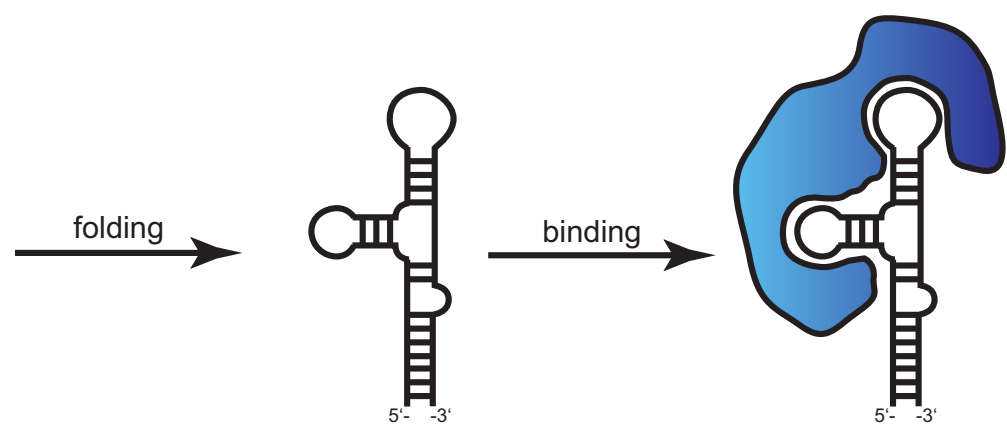

aptamer folding target-aptamer complex

B

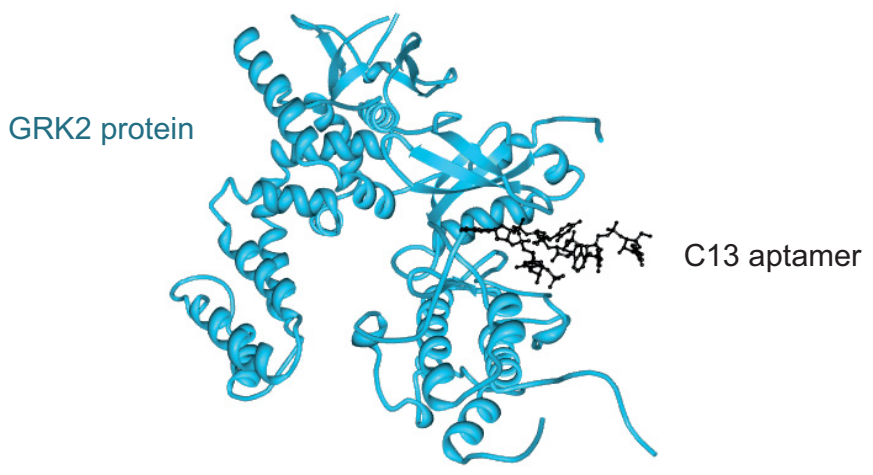

Figure 1. A, Schematic representation of aptamer binding to a target protein depending on structure formation. After the adjustment of the binding conditions, the aptamer folds into a $3 D$ structure, upon which it interacts with the target molecule (e.g., a protein), resulting in a stable target-aptamer complex. $\boldsymbol{B}$, The crystallographic structure of the $G$ protein-coupled receptor kinase 2 (GRK2)-C13 complex is depicted as an example for a target-aptamer complex-PDB ID: 3UZT (Tesmer et al., 2012). The C13 RNA aptamer (black) binds to GRK protein (blue), by mimicking adenosine triphosphate (ATP) and specifically recognizing the ATP-binding site within the GRK2 protein. Thereby, the kinase is inhibited. The structure of the GRK2-C13 complex was generated by the program protein workshop (Moreland et al., 2005).

particular enzyme is laborious and expensive and thus unlikely to keep pace with the demands of the fast-growing systems biology field, which identifies novel potential target proteins or whose characterization the rapid availability of potent and specific inhibitors will be essential (Arkin and Wells, 2004). In this regard, one advantage of aptamers is the way they are identified. They can be accessed by an in vitro selection process, which is an iterative, cyclic procedure done manually within a couple of weeks but which is also amenable to automation (Zhang et al., 2000; Cox et al., 2002). As the entire selection process is done in vitro, it allows the adjustment of the conditions under which the desired aptamer reveals its best performance to a multitude of variations. This characteristic enables the selection conditions to be adapted to those applying in the designated applications (Cho et al., 2009; Li et al., 2009), such as intracellular (Thiel and Giangrande, 2010), extracellular (Becker et al., 2010), or artificial conditions (e.g., those containing organic solvents) (Chaou et al., 2016). Furthermore, aptamers can be produced by chemical synthesis with highest accuracy and reproducibility (Ruigrok et al., 2011). Therefore, and in contrast to antibodies, aptamers do not have strong batch-to-batch variations (Ellington and Pollard, 2001; Baker, 2015); moreover, the synthetic access offers the opportunity to introduce modifications into aptamers (e.g., fluorescent reporter molecules for optical imaging in a site-specific manner)
(Farrar et al., 2014). Similar to small molecules, aptamers bind to a specific domain or catalytic cleft of a protein and thus potentially inhibit the associated protein function (e.g., kinase activity) (Lennarz et al., 2015a, b) while leaving other important protein functions and domains unaffected (Pendergrast et al., 2005) (Fig. 1B). Aptamers are also susceptible to light regulation. For example, photo-labile groups, such as $o$-nitrophenylpropyl or $o$-nitrophenylethyl can be incorporated into aptamers at specific positions by chemical synthesis (Mayer, 2009; Brieke et al., 2012). In this way, aptamers are suitable for uncaging experiments, enabling spatiotemporal control over targeted protein functions (Seyfried et al., 2017).

\section{Selection and identification of aptamers}

The identification of aptamers is achieved by an in vitro selection process, also termed SELEX (Tuerk and Gold, 1990; Stoltenburg et al., 2007). This process is a cyclic and repetitive approach, in which a synthetic nucleic acid library that contains up to $10^{15}$ different sequences and structures is incubated with a target molecule of choice, the unbound sequences are removed, the target-bound sequences are recovered and amplified by PCR or RT-PCR, depending on the nature of the nucleic acid library (Fig. 2) (Stoltenburg et al., 2007; Darmostuk et al., 2015). This cyclic process is repeated several times (5-16) until the nucleic acid population has been substantially en- 


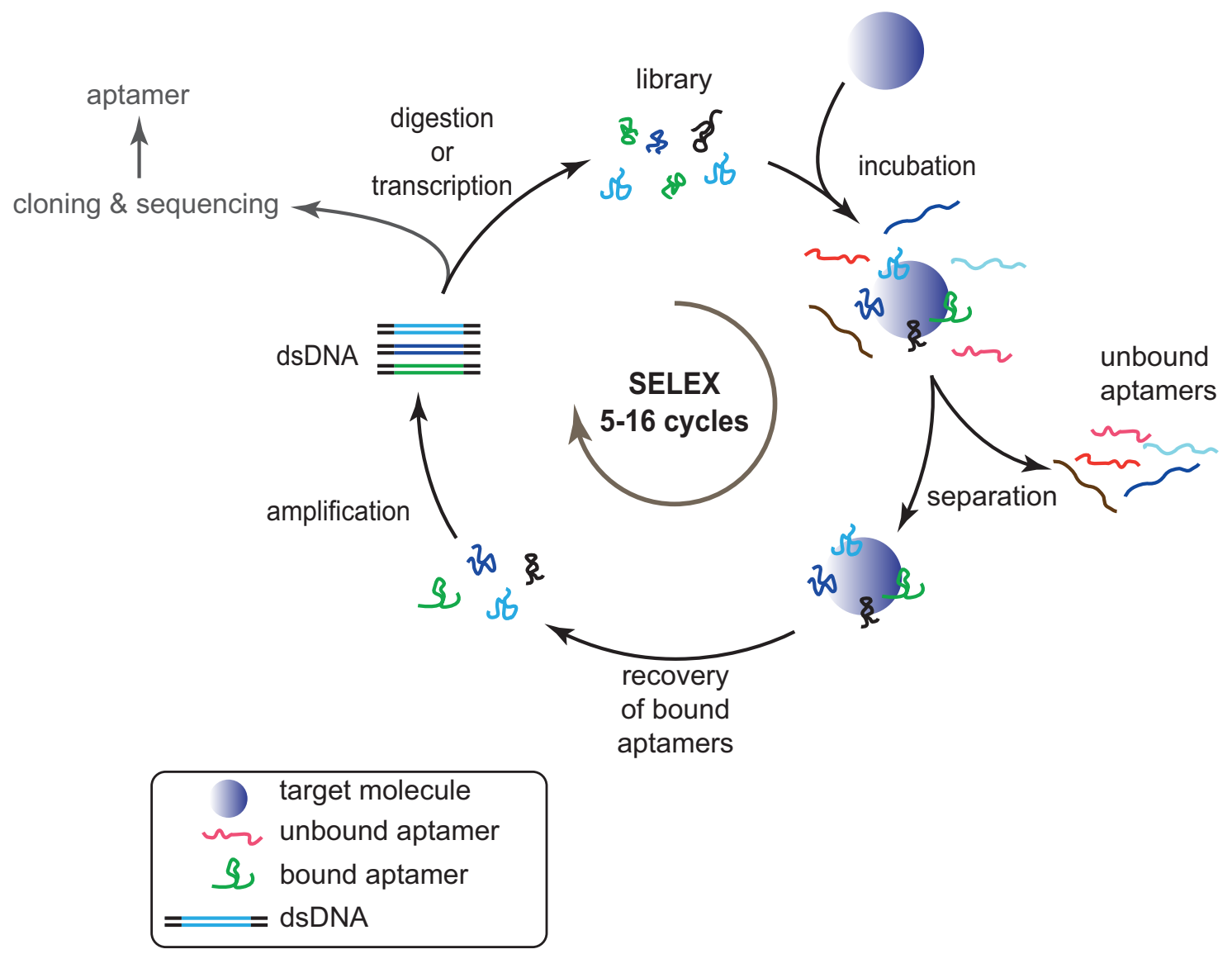

Figure 2. Schematic illustration of an in vitro selection cycle. The selection cycle starts with the incubation of the library (ssDNA or RNA) with the target molecule. After separating unbound from bound sequences, the latter are recovered and amplified by RT-PCR in the case of RNA libraries or PCR when using DNA libraries. After PCR, the single-strand nucleic acids are generated, for example, by $\lambda$-exonuclease digestion (DNA) or by in vitro transcription (RNA). The obtained library is subsequently used for the next selection cycle. After several selection (5-16) cycles, the enriched library is cloned and sequenced to identify individual monoclonal aptamers contained in the library.

riched for target-specific sequences. Nucleic acid libraries represent the largest available compound collection for screening and selection purposes to date. Monoclonal aptamer sequences are accessible through cloning and sequencing of the enriched library, whereas state-of-the-art next-generation sequencing approaches allow an indepth assessment of the selection process (Schütze et al., 2011; Tolle and Mayer, 2016). Since the first reports in 1990, a huge variety of selection methods and strategies have been described and subjected to countless improvements. These variations mainly rely on the used separation method or on chemical modifications introduced into nucleic acid libraries. Most selection strategies are based on the immobilization of the target molecule to allow the efficient separation of bound from unbound nucleic acid species within the library (Darmostuk et al., 2015). Immobilization is realized by exploiting conventional protein tags (e.g., His-, GST-, or strep-tag), which can also be used for initial target purification. Alternatively, target proteins can be modified with biotin and coupled to streptavidin modified magnetic beads or Sepharose for immobilization (Mayer and Höver, 2009; Turcheniuk et al., 2013; Darmostuk et al., 2015). The aptamer history has also seen the introduction of a series of selection protocols that circumvent the necessity of target immobilization (e.g., capture-SELEX) (Stoltenburg et al., 2012; Hamedani et al., 2015) and protocols based on capillary electrophoresis (Krylov, 2007; Yang and Bowser, 2013; Galievsky et al., 2016; Hamedani and Müller, 2016). These examples demonstrate that aptamer generation is a versatile approach, which can be adapted to individual needs.

\section{The application of aptamers as molecular tools} in neurosciences

Aptamers have made their way into versatile applications. Their use as molecular research tools in neurosciences is limited, though. Only a few studies are yet available that describe either the generation of aptamers binding "neuroscience"-related target proteins (e.g., ion channels or their application for investigating neuronal cell behavior by inhibiting specific proteins). We believe that neurosciences will benefit from aptamer technology and to demonstrate this we provide recent examples in the following section.

Signal cascades that rely on protein phosphorylation play an important role in various aspects of cellular homeostasis and is also connected to several diseases (Cohen, 2002). Thus, the demand for specific inhibitors and regulators of protein kinases and phosphatases is high and of utmost interest, not only for drug development approaches but also for endeavors that use inhibitors as chemical probes for basic sciences to dissect and analyze kinase function (Dar and Shokat, 2011).

The phosphorylation of the AMPA receptor is engaged in receptor trafficking (Wang et al., 2005). AMPA receptors are involved in excitatory synaptic transmission in the CNS and contribute to synaptic plasticity, as it is known in learning and memory processes (Boudreau and Wolf, 2005). They are heterooligomeric proteins, constituted of different combinations of four subunits GluR1-R4 (Barry and Ziff, 2002). The subunit GluR1 contains a long cytoplasmic C terminus that plays a key role in receptor trafficking to the cell surface of synapses (Passa- 
A

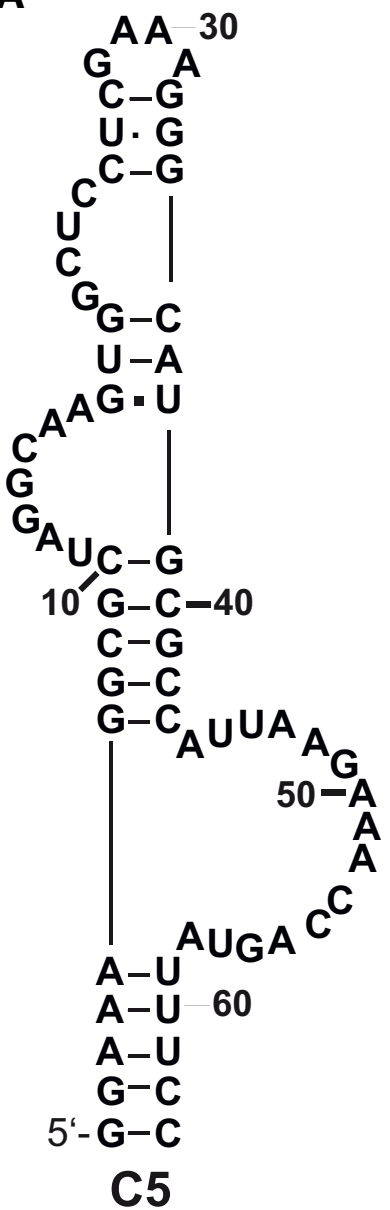

B

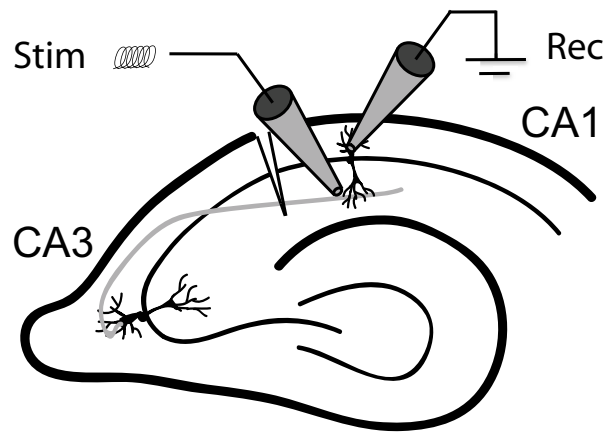

C

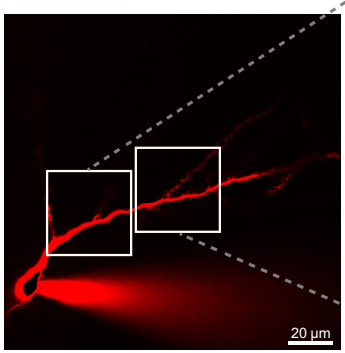

D

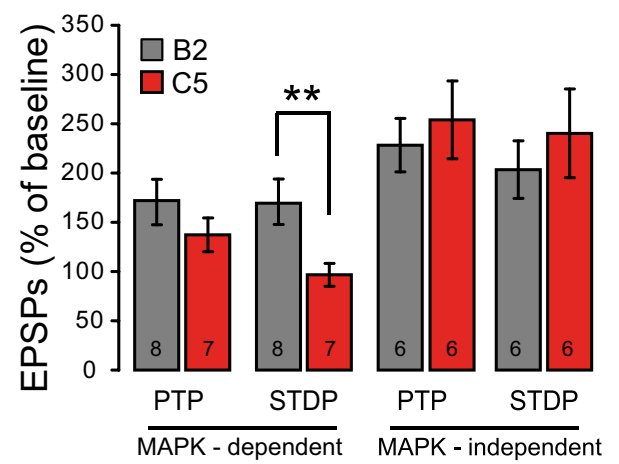

Figure 3. A, Proposed secondary structure of the RNA aptamers C5. It is a 63-mer RNA molecule forming four loops. $\boldsymbol{B}$, Recording configuration on a prepared hippocampal slice with two electrodes at a CA1 neuron. There is one stimulation (stim) and one recording (rec) electrode. C, Through the patch-clamp pipette, C5 diffuses into CA1 pyramidal neuron dendrites. Via the patch-pipette, two photo fluorescent images from two different CA1 pyramidal neurons filled with Alexa-594. D, Summary of the magnitude of the potentiation measured immediately after STDP induction (post-tetanic potentiation [PTP]) and the magnitude of stable STDP. The C5 aptamer selectively inhibited MAPK-dependent STDP. The B2 aptamer is a scrambled version of C5, acting as a nonbinding aptamer. $N$, Numbers given within the bars. ${ }^{* *} p=0.005$ (Wilcoxon Rank test). Reproduced with permission (Lennarz et al., $2015 \mathrm{~b}$ ).

faro et al., 2001). Particularly, the phosphorylation of GluR1 at the amino acid residues Ser831, Ser845, and Ser818 located at the receptor's intracellular domain, has been found to have a strong impact on AMPA-mediated neurotransmission. However, to analyze which of the three Ser residues is key to the signaling requires the specific blocking of one of the amino acids, whereas the others should remain as substrates. Liu et al. (2009) identified an RNA aptamer, termed A2, which modulates the phosphorylation of the serine-residue Ser845 of the GluR1, whereas the phosphorylation of the Ser831 and Ser818 has been found to be unaffected. This finding opens the application of aptamers toward phosphorspecific analysis and of role and contribution of specific amino acid residues in signaling cascades. Further investigations of the aptamer in neuronal networks will enable insights into the mechanism of the role of AMPA receptors in synaptic plasticity in general and classifying the role of Ser845 in particular. Albeit, intracellular availability of aptamers is still a challenge, we and others have shown that transfection (Konopka et al., 1998; Theis et al., 2004; Hwang et al., 2012), microinjection (Ishizaki et al., 1996), and expression of RNA aptamers by RNA polymerase III promoters are feasible (Thomas et al., 1997; Famulok et al., 2001; Famulok and Mayer, 2005; Fan et al., 2005).

In our own work, we recently identified an RNA aptamer, named $\mathrm{C} 5$, which specifically binds and inhibits the mitogen- activated protein kinase (MAPK) Erk1/2 (Fig. 3A) (Lennarz et al., 2015b). The aptamer recognizes the kinase in an ATPcompetitive manner and, thus, inhibits Erk2 kinase activity. C5 has been identified by an in vitro selection procedure that renders the resultant aptamers to be compatible with physiological ion conditions. This capacity allows the intracellular use of C5 (e.g., in neurons). Because aptamers are polyanionic, they cannot pass cell membranes autonomously. Lennarz et al. (2015b) overcomes this disadvantage by delivering C5 through the patch-clamp pipette. Most notably, this approach is straightforward and does not require to establish delivery systems, for example, liposome transfection, viral delivery, or by using nanoparticles that could be laborious and requires nucleic acid engineering and testing (Konopka et al., 1998; Choi et al., 2006; Ferguson et al., 2006; Hwang et al., 2012). This approach enabled the introduction of an aptamer into neuronal cells and the measurement of the change in biological activity of the target molecule in real time. With this advance, Lennarz et al. (2015b) demonstrated that C5 inhibits spike timing-dependent plasticity (STDP) in neurons through performing whole-cell patch-clamp recordings from CA1 neuron in acute hippocampal slice preparations (Fig. $3 B$ ). The diffusion of C5 into neurons through the patch-clamp pipette and its distribution in the cell were observed by two-photon microscopy. C5 was labeled with fluorescein at its $5^{\prime}$ end and, 
after provision into CA1 pyramidal neurons, the C5-related fluorescence signal could be detected in the soma, proving the rapid diffusion of C5 (Fig. 3C). Advantageously, the patch-clamp method allows to record the immediate electrical response of the investigated neuron, facilitating a very accurate controlling of intracellular signal transduction. Some forms of STDP are caused by Erk1/2 activation, whereas others have been shown to be MAPK-independent (Thomas and Huganir, 2004). Lennarz et al. (2015b) revealed that C5 is inhibiting STDP in a MAPK-dependent manner (Fig. 3D), demonstrating the high degree of C5's specificity in the blockade of intraneuronal signaling cascades. This method is, of course, not limited to C5 and the MAP kinase Erk1/2; it is applicable to any other aptamer-target combination to native neurons by any researchers who are performing patchclamp experiments.

The fundamental advantage of this approach is the simple and rapid execution. It offers a new way to investigate neurons by specifically inhibiting different components of intraneuronal signaling networks.

The Lefkowitz group (Kahsai et al., 2016) recently described RNA aptamers that bind to a prototypical G-protein-coupled receptor (GPCR), namely, the $\beta_{2}$-adrenoceptor ( $\left.\beta_{2}-\mathrm{AR}\right)$. GPCRs, also termed as seven- $\alpha$-helical transmembrane-spanning receptors, represent the largest and most versatile family of membrane receptors. The receptors are targets for many drugs for treating a broad range of diseases (e.g., asthma, neurological disorders, or immune system dysfunction) (Pierce et al., 2002; Lagerström and Schiöth, 2008). Lefkowitz and colleagues (Kahsai et al., 2016) identified aptamers that function as allosteric modulators. In this way, a precise modulation of the activation and signaling cascade of GPCR by the respective aptamers is possible. By involving next-generation sequencing and a specific selection strategy, the group identified activation state-specific RNA aptamers recognizing $\beta_{2}$-AR. The study reveals that the aptamers are able to stabilize different conformations of the $\beta_{2}$-AR receptor. One group of aptamers, termed A1, A2, and A13, interacts with high affinity with the agonist active $\beta_{2}$-AR conformation, whereas another aptamer, termed A16, showed specificity for an inverseagonist inactive $\beta_{2}$-AR conformation. With this study, the group illustrated the great potential of aptamers to act as tailored allosteric modulators of GPCRs (Kahsai et al., 2016).

\section{Limitations and opportunities of aptamers}

As all technologies and substance classes, aptamers have certain limitations, but also specific opportunities. The major bottleneck of in vitro selection experiments is an uncertain prognosis on the success, meaning whether a specific combination of target protein and nucleic acid library will yield an aptamer. This limitation is mainly attributed to the limited set of nucleotides and building blocks of which a nucleic acid library is made. The four canonical nucleotides, in conjunction with the ribose (in the case of RNA) or deoxyribose (in the case of DNA) and phosphate backbone, provide a rather limited chemical diversity, compared with the 21 proteinogenic amino acids that enable many type of molecular interaction and properties (e.g., polar, charged, basic, acidic, aromatic, and aliphatic). Hence, the success rate of in vitro selection experiments for protein targets has been found to be $\sim 30 \%$ (Gold et al., 2010). Recent developments, however, allow to overcome this limitation of nucleic acids. For example, aptamervariants termed SOMAmers or clickmers comprise at least one nucleotide modified at the C5 position of uridine to bear an additional chemical entity (Tolle and Mayer, 2013; Rohloff et al., 2014; Tolle et al., 2015). These approaches have been shown to enhance the success rate of selection endeavors substantially (Gold et al., 2010). In addition to clickmers and SOMAmers, various approaches have been developed to generate modified nucleic acid libraries using different chemistries and additional artificial base-pairs, which have been successfully used in selection experiments (Eaton, 1997; Gold et al., 2010; Vaught et al., 2010; Hirao and Kimoto, 2012; Tolle and Mayer, 2013; Pinheiro and Holliger, 2014; Diafa and Hollenstein, 2015; Tolle et al., 2015; Lapa et al., 2016).

An important aspect to be considered in aptamer applications is also the impact of ionic strength on aptamer conformation and, thus, performance. As aptamers are generated in vitro under defined conditions, they are perfectly adapted to these. Any alterations of the environmental conditions may have a negative impact on the binding properties of an aptamer to its specific target molecules. However, as the selection process is done in vitro, the exact conditions of a final application can be considered already during the generation process. Nevertheless, once an aptamer has been identified, its compatibility with certain environmental conditions can be adapted by mutational analysis and appropriate reselection strategies.

The inability of aptamers to cross cell membranes autonomously (e.g., passive diffusion represents a further limitation in their applicability and is mainly attributed to their macromolecules and polyanionic nature). Nevertheless, several options are available to overcome this restraint. Aptamers are compatible with state-of-the-art methods to achieve intracellular availability (e.g., transfection with liposomes) (Konopka et al., 1998; Hwang et al., 2012), through plasmid or viral delivery (Choi et al., 2006), or using nanoparticles (Ryou et al., 2011). As described above, the whole-cell patch-clamp technology offers an elegant and straightforward alternative; and most importantly, it is compatible with primary neuron cell investigations (Lennarz et al., 2015b). Although in experiments with isolated cells and cell culture, the intracellular delivery issue of aptamers might be practicable, the situation in vivo is more complicated, in particular, when the CNS is the targeted tissue of choice, as these tissues are protected by well-organized barriers. These barriers (e.g., the blood-brain barrier) can hardly be passively transmitted by aptamers and other macromolecules. However, performing selection experiments in vivo enabled the identification of aptamers that indeed pass the blood-brain barrier in mice and penetrate into the brain parenchyma (Cheng et al., 2013). These aptamers might be exploitable as Trojan horses for the noninvasive delivery of specific compounds, which are attached to the aptamer, to the brain facilitating in vivo studies (de Boer and Gaillard, 2007).

Generally, the selection of aptamers is quite challenging; and in contrast to siRNA molecules, they cannot be designed based on sequence information. Albeit superficially, the process as depicted in Figure 2 seems to be straightforward. Nevertheless, there are many issues that need to be considered before a successful selection experiment can be conducted. Target proteins need to be purified and remain functional when embedded in a selection process, the library design and amplification performance is also key to yield a satisfactory result and to avoid bottlenecks. To our experience, it has been proven successful to approach experts in the field early on and to seek support in the design, performance, and analysis of selection experiments.

\section{Conclusion}

Aptamer technology has emerged into almost every field in the life sciences since its inauguration $>25$ years ago. A multitude of aptamers were selected and characterized, binding to a broad 
range of diverse target molecules. Because of the particular properties of aptamers, they are used as tools for diagnostic and therapeutic applications. In this TechSight, we demonstrated that due to their specific characteristics, aptamers might become a valuable tool for basic research in the field of neurosciences. Systems (neuro)biology approaches will uncover a large number of interesting target proteins for which specific and potent inhibitors are required. A precise analysis of the protein functions in neurons and neuronal circuits calls for the rapid identification and availability of specific inhibitory compounds. In this regard, the identification of aptamers may open a novel path for getting hands on inhibitors in a sophisticated and timely manner. Together, we believe that aptamers will become a valuable research tool for neurological studies, and future endeavors in which researches from the aptamer and neurosciences research areas will work closely together will reveal its full potential.

\section{References}

Arkin MR, Wells JA (2004) Small-molecule inhibitors of protein-protein interactions: progressing towards the dream. Nat Rev Drug Discov 3:301317. CrossRef Medline

Avci-Adali M, Steinle H, Michel T, Schlensak C, Wendel HP (2013) Potential capacity of aptamers to trigger immune activation in human blood. PLoS One 8:e68810. CrossRef Medline

Baker M (2015) Reproducibility crisis: blame it on the antibodies. Nature 521:274-276. CrossRef Medline

Balogh Z, Lautner G, Bardóczy V, Komorowska B, Gyurcsányi RE, Mészáros $\mathrm{T}$ (2010) Selection and versatile application of virus-specific aptamers. FASEB J 24:4187-4195. CrossRef Medline

Barry MF, Ziff EB (2002) Receptor trafficking and the plasticity of excitatory synapses. Curr Opin Neurobiol 12:279-286. CrossRef Medline

Becker RC, Povsic T, Cohen MG, Rusconi CP, Sullenger B (2010) Nucleic acid aptamers as antithrombotic agents: opportunities in extracellular therapeutics. Thromb Haemost 103:586-595. CrossRef Medline

Boudreau AC, Wolf ME (2005) Behavioral sensitization to cocaine is associated with increased AMPA receptor surface expression in the nucleus accumbens. J Neurosci 25:9144-9151. CrossRef Medline

Brieke C, Rohrbach F, Gottschalk A, Mayer G, Heckel A (2012) Light-controlled tools. Angew Chem Int Ed Engl 51:8446-8476. CrossRef Medline

Chames P, Van Regenmortel M, Weiss E, Baty D (2009) Therapeutic antibodies: successes, limitations and hopes for the future. Br J Pharmacol 157:220-233. CrossRef Medline

Chaou T, Vialet B, Azéma L (2016) DNA aptamer selection in methanolic media: adenine-aptamer as proof-of-concept. Methods 97:11-19. CrossRef Medline

Cheng C, Chen YH, Lennox KA, Behlke MA, Davidson BL (2013) In vivo SELEX for identification of brain-penetrating aptamers. Mol Ther Nucleic Acids 2:e67. CrossRef Medline

Cho EJ, Lee JW, Ellington AD (2009) Applications of aptamers as sensors. Annu Rev Anal Chem 2:241-264. CrossRef Medline

Choi KH, Park MW, Lee SY, Jeon MY, Kim MY, Lee HK, Yu J, Kim HJ, Han K, Lee H, Park K, Park WJ, Jeong S (2006) Intracellular expression of the T-cell factor-1 RNA aptamer as an intramer. Mol Cancer Ther 5:24282434. CrossRef Medline

Cohen P (2002) The origins of protein phosphorylation. Nat Cell Biol 4:E127-E130. CrossRef Medline

Cox JC, Rajendran M, Riedel T, Davidson EA, Sooter LJ, Bayer TS, SchmitzBrown M, Ellington AD (2002) Automated acquisition of aptamer sequences. Comb Chem High Throughput Screen 5:289-299. CrossRef Medline

Dar AC, Shokat KM (2011) The evolution of protein kinase inhibitors from antagonists to agonists of cellular signaling. Annu Rev Biochem 80:769795. CrossRef Medline

Darmostuk M, Rimpelova S, Gbelcova H, Ruml T (2015) Current approaches in SELEX: an update to aptamer selection technology. Biotechnol Adv 33:1141-1161. CrossRef Medline

Dassie JP, Giangrande PH (2013) Current progress on aptamer-targeted oligonucleotide therapeutics. Ther Deliv 4:1527-1546. CrossRef Medline

de Boer AG, Gaillard PJ (2007) Drug targeting to the brain. Annu Rev Pharmacol Toxicol 47:323-355. CrossRef Medline
Diafa S, Hollenstein M (2015) Generation of aptamers with an expanded chemical repertoire. Molecules 20:16643-16671. CrossRef Medline

Eaton BE (1997) The joys of in vitro selection: chemically dressing oligonucleotides to satiate protein targets. Curr Opin Chem Biol 1:10-16. CrossRef Medline

Ellington AD, Szostak JW (1990) In vitro selection of RNA molecules that bind specific ligands. Nature 346:818-822. CrossRef Medline

Ellington AD, Szostak JW (1992) Selection in vitro of single-stranded DNA molecules that fold into specific ligand-binding structures. Nature 355: 850-852. CrossRef Medline

Ellington A, Pollard JD Jr (2001) Synthesis and purification of oligonucleotides. Curr Protoc Mol Biol Chapter 2:Unit 2.11. CrossRef Medline

Famulok M, Mayer G (2005) Intramers and aptamers: applications in protein-function analyses and potential for drug screening. Chembiochemistry 6:19-26. CrossRef Medline

Famulok M, Mayer G, Blind M (2000) Nucleic acid aptamers-from selection in vitro to applications in vivo. Acc Chem Res 33:591-599. CrossRef Medline

Famulok M, Blind M, Mayer G (2001) Intramers as promising new tools in functional proteomics. Chem Biol 8:931-939. CrossRef Medline

Fan X, Shi H, Lis JT (2005) Distinct transcriptional responses of RNA polymerases I, II and III to aptamers that bind TBP. Nucleic Acids Res 33:838845. CrossRef Medline

Farrar CT, William CM, Hudry E, Hashimoto T, Hyman BT (2014) RNA aptamer probes as optical imaging agents for the detection of amyloid plaques. PLoS One 9:e89901. CrossRef Medline

Ferguson MR, Rojo DR, Somasunderam A, Thiviyanathan V, Ridley BD, Yang X, Gorenstein DG (2006) Delivery of double-stranded DNA thioaptamers into HIV-1 infected cells for antiviral activity. Biochem Biophys Res Commun 344:792-797. CrossRef Medline

Galievsky VA, Stasheuski AS, Krylov SN (2016) Getting the best sensitivity from on-capillary fluorescence detection in capillary electrophoresis: a tutorial. Anal Chim Acta 935:58-81. CrossRef Medline

Gold L, Ayers D, Bertino J, Bock C, Bock A, Brody EN, Carter J, Dalby AB, Eaton BE, Fitzwater T, Flather D, Forbes A, Foreman T, Fowler C, Gawande B, Goss M, Gunn M, Gupta S, Halladay D, Heil J, et al. (2010) Aptamer-based multiplexed proteomic technology for biomarker discovery. PLoS One 5:e15004. CrossRef Medline

Gragoudas ES, Adamis AP, Cunningham ET Jr, Feinsod M, Guyer DR (2004) Pegaptanib for neovascular age-related macular degeneration. N Engl J Med 351:2805-2816. CrossRef Medline

Hamedani NS, Müller J (2016) Capillary electrophoresis for the selection of DNA aptamers recognizing activated protein C. In: Nucleic acid aptamers: selection, characterization, and application (Mayer G, ed), pp 61-75. New York: Springer.

Hamedani NS, Blumke F, Tolle F, Rohrbach F, Ruhl H, Oldenburg J, Mayer G, Potzsch B, Muller J (2015) Capture and Release (CaR): a simplified procedure for one-tube isolation and concentration of single-stranded DNA during SELEX. Chem Commun 51:1135-1138. CrossRef Medline

Hartmann R, Norby PL, Martensen PM, Jorgensen P, James MC, Jacobsen C, Moestrup SK, Clemens MJ, Justesen J (1998) Activation of 2'-5' oligoadenylate synthetase by single-stranded and double-stranded RNA aptamers. J Biol Chem 273:3236-3246. CrossRef Medline

Hirao I, Kimoto M (2012) Unnatural base pair systems toward the expansion of the genetic alphabet in the central dogma. Proc Jpn Acad Ser B Phys Biol Sci 88:345-367. CrossRef Medline

Hoellenriegel J, Zboralski D, Maasch C, Rosin NY, Wierda WG, Keating MJ, Kruschinski A, Burger JA (2014) The Spiegelmer NOX-A12, a novel CXCL12 inhibitor, interferes with chronic lymphocytic leukemia cell motility and causes chemosensitization. Blood 123:1032-1039. CrossRef Medline

Holeman LA, Robinson SL, Szostak JW, Wilson C (1998) Isolation and characterization of fluorophore-binding RNA aptamers. Fold Des 3:423431. CrossRef Medline

Hwang SY, Sun HY, Lee KH, Oh BH, Cha YJ, Kim BH, Yoo JY (2012) 5'Triphosphate-RNA-independent activation of RIG-I via RNA aptamer with enhanced antiviral activity. Nucleic Acids Res 40:2724-2733. CrossRef Medline

Ishizaki J, Nevins JR, Sullenger BA (1996) Inhibition of cell proliferation by an RNA ligand that selectively blocks E2F function. Nat Med 2:13861389. CrossRef Medline

Kahsai AW, Wisler JW, Lee J, Ahn S, Cahill Iii TJ, Dennison SM, Staus DP, 
Thomsen AR, Anasti KM, Pani B, Wingler LM, Desai H, Bompiani KM, Strachan RT, Qin X, Alam SM, Sullenger BA, Lefkowitz RJ (2016) Conformationally selective RNA aptamers allosterically modulate the beta2adrenoceptor. Nat Chem Biol 12:709-716. CrossRef Medline

Konopka K, Düzgünes N, Rossi J, Lee NS (1998) Receptor ligand-facilitated cationic liposome delivery of anti-HIV-1 Rev-binding aptamer and ribozyme DNAs. J Drug Target 5:247-259. CrossRef Medline

Krylov SN (2007) Kinetic CE: foundation for homogeneous kinetic affinity methods. Electrophoresis 28:69-88. CrossRef Medline

Lagerström MC, Schiöth HB (2008) Structural diversity of G proteincoupled receptors and significance for drug discovery. Nat Rev Drug Discov 7:339-357. CrossRef Medline

Lapa SA, Chudinov AV, Timofeev EN (2016) The toolbox for modified aptamers. Mol Biotechnol 58:79-92. CrossRef Medline

Lennarz S, Heider E, Blind M, Mayer G (2015a) An aptamer to the MAP kinase insert region. ACS Chem Biol 10:320-327. CrossRef Medline

Lennarz S, Alich TC, Kelly T, Blind M, Beck H, Mayer G (2015b) Selective aptamer-based control of intraneuronal signaling. Angew Chem Int Ed Engl 54:5369-5373. CrossRef Medline

Li N, Ebright JN, Stovall GM, Chen X, Nguyen HH, Singh A, Syrett A, Ellington $\mathrm{AD}$ (2009) Technical and biological issues relevant to cell typing with aptamers. J Proteome Res 8:2438-2448. CrossRef Medline

Liu Y, Sun QA, Chen Q, Lee TH, Huang Y, Wetsel WC, Michelotti GA, Sullenger BA, Zhang X (2009) Targeting inhibition of GluR1 Ser845 phosphorylation with an RNA aptamer that blocks AMPA receptor trafficking. J Neurochem 108:147-157. CrossRef Medline

Mayer G (2009) The chemical biology of aptamers. Angew Chem Int Ed Engl 48:2672-2689. CrossRef Medline

Mayer G, Höver T (2009) In vitro selection of ssDNA aptamers using biotinylated target proteins. In: Nucleic acid and peptide aptamers: methods and protocols (Mayer G, ed), pp 19-32. Totowa, NJ: Humana.

Meyer C, Hahn U, Rentmeister A (2011) Cell-specific aptamers as emerging therapeutics. J Nucleic Acids 2011:904750. CrossRef Medline

Michaud M, Jourdan E, Villet A, Ravel A, Grosset C, Peyrin E (2003) A DNA aptamer as a new target-specific chiral selector for HPLC. J Am Chem Soc 125:8672-8679. CrossRef Medline

Moreland JL, Gramada A, Buzko OV, Zhang Q, Bourne PE (2005) The Molecular Biology Toolkit (MBT): a modular platform for developing molecular visualization applications. BMC Bioinformatics 6:21. CrossRef Medline

Ng EW, Shima DT, Calias P, Cunningham ET Jr, Guyer DR, Adamis AP (2006) Pegaptanib, a targeted anti-VEGF aptamer for ocular vascular disease. Nat Rev Drug Discov 5:123-132. CrossRef Medline

Passafaro M, Piëch V, Sheng M (2001) Subunit-specific temporal and spatial patterns of AMPA receptor exocytosis in hippocampal neurons. Nat Neurosci 4:917-926. CrossRef Medline

Pei X, Zhang J, Liu J (2014) Clinical applications of nucleic acid aptamers in cancer. Mol Clin Oncol 2:341-348. CrossRef Medline

Pendergrast PS, Marsh HN, Grate D, Healy JM, Stanton M (2005) Nucleic acid aptamers for target validation and therapeutic applications. J Biomol Tech 16:224-234. Medline

Pfeiffer F, Mayer G (2016) Selection and biosensor application of aptamers for small molecules. Front Chem 4:25. CrossRef Medline

Pierce KL, Premont RT, Lefkowitz RJ (2002) Seven-transmembrane receptors. Nat Rev Mol Cell Biol 3:639-650. CrossRef Medline

Pinheiro VB, Holliger P (2014) Towards XNA nanotechnology: new materials from synthetic genetic polymers. Trends Biotechnol 32:321-328. CrossRef Medline

Robertson DL, Joyce GF (1990) Selection in vitro of an RNA enzyme that specifically cleaves single-stranded DNA. Nature 344:467-468. CrossRef Medline

Rohloff JC, Gelinas AD, Jarvis TC, Ochsner UA, Schneider DJ, Gold L, Janjic N (2014) Nucleic acid ligands with protein-like side chains: modified aptamers and their use as diagnostic and therapeutic agents. Mol Ther Nucleic Acids 3:e201. CrossRef Medline

Ruigrok VJ, Levisson M, Eppink MH, Smidt H, van der Oost J (2011) Alternative affinity tools: more attractive than antibodies? Biochem J 436:1-13. CrossRef Medline

Ryou SM, Kim JM, Yeom JH, Hyun S, Kim S, Han MS, Kim SW, Bae J, Rhee S, Lee K (2011) Gold nanoparticle-assisted delivery of small, highly structured RNA into the nuclei of human cells. Biochem Biophys Res Commun 416:178-183. CrossRef Medline

Schütze T, Wilhelm B, Greiner N, Braun H, Peter F, Mörl M, Erdmann VA, Lehrach H, Konthur Z, Menger M, Arndt PF, Glökler J (2011) Probing the SELEX process with next-generation sequencing. PLoS One 6:e29604. CrossRef Medline

Seyfried P, Eiden L, Grebenovsky N, Mayer G, Heckel A (2017) Phototethers for the (multi-)cyclic, conformational caging of long oligonucleotides. Angew Chem Int Ed Engl 56:359-363. CrossRef Medline

Stoltenburg R, Reinemann C, Strehlitz B (2007) SELEX: a (r)evolutionary method to generate high-affinity nucleic acid ligands. Biomol Eng 24: 381-403. CrossRef Medline

Stoltenburg R, Nikolaus N, Strehlitz B (2012) Capture-SELEX: selection of DNA aptamers for aminoglycoside antibiotics. J Anal Methods Chem 2012:415697. CrossRef Medline

Tan W, Donovan MJ, Jiang J (2013) Aptamers from cell-based selection for bioanalytical applications. Chem Rev 113:2842-2862. CrossRef Medline

Tesmer VM, Lennarz S, Mayer G, Tesmer JJ (2012) Molecular mechanism for inhibition of g protein-coupled receptor kinase 2 by a selective RNA aptamer. Structure 20:1300-1309. CrossRef Medline

Thakur MS, Ragavan KV (2013) Biosensors in food processing. J Food Sci Technol 50:625-641. CrossRef Medline

Theis MG, Knorre A, Kellersch B, Moelleken J, Wieland F, Kolanus W, Famulok M (2004) Discriminatory aptamer reveals serum response element transcription regulated by cytohesin-2. Proc Natl Acad Sci U S A 101: 11221-11226. CrossRef Medline

Thiel KW, Giangrande PH (2010) Intracellular delivery of RNA-based therapeutics using aptamers. Ther Deliv 1:849-861. CrossRef Medline

Thomas GM, Huganir RL (2004) MAPK cascade signalling and synaptic plasticity. Nat Rev Neurosci 5:173-183. CrossRef Medline

Thomas M, Chédin S, Carles C, Riva M, Famulok M, Sentenac A (1997) Selective targeting and inhibition of yeast RNA polymerase II by RNA aptamers. J Biol Chem 272:27980-27986. CrossRef Medline

Tolle F, Mayer G (2013) Dressed for success: applying chemistry to modulate aptamer functionality. Chem Sci 4:60-67. CrossRef

Tolle F, Mayer G (2016) Preparation of SELEX Samples for next-generation sequencing. Methods Mol Biol 1380:77-84. CrossRef Medline

Tolle F, Brändle GM, Matzner D, Mayer G (2015) A versatile approach towards nucleobase-modified aptamers. Angew Chem Int Ed Engl 54: 10971-10974. CrossRef Medline

Tuerk C, Gold L (1990) Systematic evolution of ligands by exponential enrichment: RNA ligands to bacteriophage T4 DNA polymerase. Science 249:505-510. CrossRef Medline

Tuerk C, MacDougal S, Gold L (1992) RNA pseudoknots that inhibit human immunodeficiency virus type 1 reverse transcriptase. Proc Natl Acad Sci U S A 89:6988-6992. CrossRef Medline

Turcheniuk K, Tarasevych AV, Kukhar VP, Boukherroub R, Szunerits S (2013) Recent advances in surface chemistry strategies for the fabrication of functional iron oxide based magnetic nanoparticles. Nanoscale 5:10729-10752. CrossRef Medline

Vaught JD, Bock C, Carter J, Fitzwater T, Otis M, Schneider D, Rolando J, Waugh S, Wilcox SK, Eaton BE (2010) Expanding the chemistry of DNA for in vitro selection. J Am Chem Soc 132:4141-4151. CrossRef Medline

Wang AZ, Farokhzad OC (2014) Current progress of aptamer-based molecular imaging. J Nucl Med 55:353-356. CrossRef Medline

Wang JQ, Arora A, Yang L, Parelkar NK, Zhang G, Liu X, Choe ES, Mao L (2005) Phosphorylation of AMPA receptors: mechanisms and synaptic plasticity. Mol Neurobiol 32:237-249. CrossRef Medline

Win MN, Liang JC, Smolke CD (2009) Frameworks for programming biological function through RNA parts and devices. Chem Biol 16:298-310. CrossRef Medline

Yang J, Bowser MT (2013) Capillary electrophoresis-SELEX selection of catalytic DNA aptamers for a small-molecule porphyrin target. Anal Chem 85:1525-1530. CrossRef Medline

Zhang H, Hamasaki A, Toshiro E, Aoyama Y, Ito Y (2000) Automated in vitro selection to obtain functional oligonucleotides. Nucleic Acids Symp Ser 44:219-220. CrossRef Medline

Zhou J, Rossi J (2016) Aptamers as targeted therapeutics: current potential and challenges. Nat Rev Drug Discov. Advance online publication. Retrieved Nov. 3, 2016. CrossRef Medline 